\title{
Learning English Conditional Structures
}

\author{
Luu Trong Tuan \\ University for Natural Resources and Environment, Ho Chi Minh City (UNRE-HCMC); \\ University of Social Sciences and Humanities, Ho Chi Minh City (USSH-HCMC), Vietnam \\ Email: luutrongtuan@vnn.vn
}

\begin{abstract}
This research is an endeavour to examine problems EFL learners encountered in learning English conditional structures at University for Natural Resources and Environment, Ho Chi Minh City (UNREHCMC) as well as causes behind these problems. These two aims were reached through responses to the survey questionnaire and the interviews. The influence of the mother tongue on learning English conditional structures should be taken into due consideration in the course of teaching and learning English conditional structures.
\end{abstract}

Index Terms-English conditional structure, language learning, EFL

\section{INTRODUCTION}

English is deemed to be the only language that truly links the whole world together. Without English, the whole world may not be as united as it is today. With respect to the vast global presence of this language, $85 \%$ of international organizations in the world make official use of English, at least 85\% of the world's films are in English and more than $65 \%$ of scientific papers in several important academic fields are published in English.

English language has four fundamental skills: speaking, listening, reading and writing and a good learner is one who can master these skills. However, in order to have good knowledge of these skills, the learners need a good understanding of grammar, which is also the foundation for learning the other aspects. Of all basic grammatical points, English conditional structure is an important one which should be put into special consideration. English conditional structure plays an important part in English Grammar and mastering it contributes greatly to students' English performance. English conditionals require coordination of verb forms in both the if and the result clauses and the fact that verb forms often do not retain their normal temporal meaning makes it even more complex. English conditional structures were selected in the current research for their structural complexity for ESL (English as second language) and EFL (English as foreign language) students (Celce-Murcia and Larsen-Freeman, 1999). In a survey of the most challenging English grammar teaching task encountered by ESL teachers in Los Angeles area, Covitt (1976) concluded that conditional sentences ranked fifth. In reality, most students at University for Natural Resources and Environment, Ho Chi Minh City (UNRE-HCMC), also find it difficult to understand this point well. These shortcomings are caused not only by themselves but also by other factors such as teaching methods and materials. What has been abovementioned encourages the author to conduct this research with the aim of investigating the existing problems and helping students get over them by providing some implications for teaching and learning English conditional structure. This research is guided by the two ensuing questions:

1. What are the problems that the EFL students tend to encounter in learning English conditional structures?

2. What are the possible causes of these problems?

\section{LITERATURE REVIEW}

Factors affecting the students' learning of grammar encompass learner, teacher, and grammar materials.

\section{The learner}

The learner plays an important in her/his second language success. Besides the aptitude of each person, which is the ability to make and recall associations between words and phrases in a native and a second language (Gass and Selinker, 1994), the learners also need to take risks and have appropriate learning strategies. Risk taking has been defined as a situation where an individual has to make a decision involving choice between alternatives of different desirability; the outcome of the choice is uncertain; there is a possibility of failure. To say that an individual is a risk taker is to say that she or he generally is more willing to take risks than the average person. Good language learners must be willing to guess, to appear foolish in order to communicate, and to use what knowledge they do have of the target language in order to create novel utterances. Thus, risk taking should be based on a background of general behaviour. And learning strategy is steps or actions taken by learners to improve the development of their language skills. Moreover, Gass and Selinker (1994) also emphasized the importance of students' aptitude in the second language acquisition. They stated that the relationship between aptitude and second language learning success is an important one since opinions about aptitude can have enormous implications in our everyday lives. If aptitude measures are used to discourage individuals from studying foreign languages and if the measures are not accurate, then certain students will be unfairly prevented from receiving whatever advantages may accrue from a knowledge of other languages. 


\section{The teacher}

The teacher is the dynamic force of the school. A school without a teacher is just like a body without the soul. All the teachers who get prepared will know how to set up rules in the classroom. The learners who are motivated will learn another language faster and to a greater degree (Gass and Selinker, 1994). Motivation appears to be the second strongest predictor of success, trailing only aptitude (Skehan, 1989). Four aspects related to motivation encompass a goal, effortful behaviour, a desire to attain the goal and favourable attitudes toward the activity in question. So being able to master an English grammar point depends a lot on the teacher's motivation.

\section{Grammar materials}

After some hours in the class, the students have to learn a lot from the coursebooks, especially for grammar subject, grammar materials have a crucial role in helping the learners better understand. So the differences in explaining one grammar point of different books will make the learners confused.

\section{MethodOLOGY}

\section{A. Participants}

The participants were 98 EFL students at University for Natural Resources and Environment, Ho Chi Minh City (UNRE-HCMC), who involved a questionnaire survey and a test. The student sample was described in terms of gender, age and English-learning experience in Table 1.

TABLE 1.

STUDENTS' BACKGROUND INFORMATION

\begin{tabular}{|c|c|c|c|}
\hline \multicolumn{4}{|c|}{ Student sample } \\
\hline Size & \multicolumn{3}{|c|}{98} \\
\hline & Male & & Female \\
\hline Gender & $6(6.12 \%)$ & & $92(93.88 \%)$ \\
\hline & Under 18 & $18-20$ & Over 20 \\
\hline Age group & $3(3.06 \%)$ & $67(68.37 \%)$ & $28(28.57 \%)$ \\
\hline \multirow{2}{*}{$\begin{array}{l}\text { English-learning } \\
\text { experience }\end{array}$} & 3 years & & 7 years \\
\hline & $5(5.10 \%)$ & & $93(94.90 \%)$ \\
\hline
\end{tabular}

In order to get more necessary information about the students' understanding of how to use English conditional structures, all 15 teachers of the Department of Foreign Languages were invited to take part in interviews.

\section{B. Instruments}

\section{Survey questionnaire}

In order to get information from a large number of subjects, questionnaire was utilized as the main instrument for the study. According to Nunan (1994, p. 143), the questionnaire is a relatively popular means of collecting data. It enables the researcher to collect data in field settings, and the data themselves are amenable to quantification. For this reason, questionnaire is the most widely-used technique for obtaining information from subjects.

The questionnaire for students was composed of two parts. The first part contained some questions with four possible answers; the readers just chose one of them for each question. These questions were aimed to gather information about their general background, their knowledge about English conditional structures and some common mistakes that may be often committed by students. The second part was open questions. These questions were primarily focused on the English materials which were currently used in teaching and learning English Grammar, their ways of practicing English conditional structures and some more possible mistakes that may happen in their learning process.

\section{Interviews}

All the questions used for the interview with teachers focused on four points: The first part was composed of two questions focusing on the informants' awareness of their learners' English background; the second part sought to examine the informants' opinions on their learners' common mistakes in learning English conditional structures; the next part was to ask the informants to find out the reasons why students often committed such mistakes; and the final part aimed to get the informants' suggestions for helping the students effectively learn English conditional structures.

\section{FINDINGS AND DISCUSSIONS}

\section{A. Students' Responses to Questionnaire}

As displayed in Table 1, nearly all the informants have been studying English for seven years (93 out of 98 informants had 7 years, and the rest had 3 years), and the aspects of English they studied most in high schools was grammar. This fact shows that English conditional structures are no longer strange or new to these students, and studying at this university gives them more chances to review and apply this point more in writing and speaking. However, English grammar is so complicated that students still make lots of mistakes despite the fact that they did spend a lot of time on learning it at high school. The data in Table 2 shows that students' grammar knowledge is still the problem needed to be paid due consideration. 
TABLE 2.

STUDENTS' EVALUATION OF THEIR ENGLISH GRAMMAR KNOWLEDGE AND PERFORMANCE

\begin{tabular}{|c|c|c|c|c|c|}
\hline Question 6 & Very good & Fairly good & Poor & Very poor & Total \\
\hline Evaluate your knowledge of English & 0 & $48(48.98 \%)$ & & 3 & \\
\hline grammar & $(0 \%)$ & & $47(47.96 \%)$ & $(3.06 \%)$ & $98(100 \%)$ \\
\hline Question 7 & Yes/ Usually & Sometimes & No/Rarely & Unsure & Total \\
\hline $\begin{array}{l}\text { Did you get good results in English } \\
\text { grammar tests? }\end{array}$ & $8(8.16 \%)$ & $73(74.49 \%)$ & $10(10.20 \%)$ & $7(7.15 \%)$ & $98(100 \%)$ \\
\hline
\end{tabular}

\section{Students' understanding of English conditional structures}

Questions 8 and 9 were designed to examine the difficulties students may encounter while acquiring aspects of English conditional structures (see Table 3).

TABLE 3.

UNDERSTANDING ASPECTS OF ENGLISH CONDITIONAL STRUCTURES

\begin{tabular}{|c|c|c|c|c|c|c|}
\hline & Never & Rarely & Sometimes & Usually & Always & Total \\
\hline $\begin{array}{l}\text { Question } 8 \\
\text { Have difficulty in } \\
\text { distinguishing conditional } \\
\text { sentence types }\end{array}$ & $\begin{array}{l}3 \\
(3.06 \%)\end{array}$ & $14(14.29 \%)$ & $\begin{array}{l}56 \\
(57.14 \%)\end{array}$ & $\begin{array}{l}15 \\
(15.31 \%)\end{array}$ & $10(10.20 \%)$ & $\begin{array}{l}98 \\
(100 \%)\end{array}$ \\
\hline $\begin{array}{l}\text { Question } 9 \\
\text { Have difficulty in } \\
\text { understanding and using } \\
\text { conditional adverbs }\end{array}$ & $\begin{array}{l}9 \\
(9.18 \%)\end{array}$ & $46(46.94 \%)$ & $33(33.68 \%)$ & $10(10.20 \%)$ & $\begin{array}{l}0 \\
(0 \%)\end{array}$ & $98(100 \%)$ \\
\hline
\end{tabular}

The data in Table 3 reveals that only $3(3.06 \%)$ of the respondents never had any difficulties in using the three basic types of English conditional sentence while 56 (57.14\%) still couldn't recognize how to use these conditional sentence types.

Question 9 focused on the conditional adverbs embracing if, only if, unless, otherwise. 9 (9.18\%) and 46 (46.94\%) respondents chose 'never' or 'rarely' for the difficulty in using conditional adverbs respectively. These high percentages prove that these aspects of English conditional structures are easier than the distinguishing conditional sentence types. 0 $(0 \%)$ respondent made the choice of 'always', only $10(10.20 \%)$ chose 'usually' while the higher percentage 33 (33.68\%) was for 'sometimes'.

Although our informants spent a long time studying English grammar at high school, they didn't have enough time for speaking, listening or writing, their understanding of English conditional structures still needs to be put into consideration. Teachers must find out whether this problem comes from the teachers' teaching method in the classroom or from some grammar materials or this is affected by their mother tongue.

All these were examined through questions 14 and 15 in the survey questionnaire. Responses to these two questions are exhibited in Table 4.

TABLE 4.

UNDERSTANDING ENGLISH CONDITIONAL STRUCTURES FROM THE TEACHER'S INSTRUCTION OR GRAMMAR BOOKS

\begin{tabular}{|c|c|c|c|c|c|c|}
\hline & Never & Rarely & Sometimes & Usually & Always & Total \\
\hline $\begin{array}{l}\text { Question } 10 \\
\text { Have difficulty in understanding the } \\
\text { English conditional structures explained } \\
\text { by the teacher in the classroom }\end{array}$ & $\begin{array}{l}3 \\
(3.06 \%)\end{array}$ & $\begin{array}{l}28 \\
(28.57 \%)\end{array}$ & $\begin{array}{l}23 \\
(23.47 \%)\end{array}$ & $\begin{array}{l}40 \\
(40.82 \%)\end{array}$ & $\begin{array}{l}4 \\
(4.08 \%)\end{array}$ & $98(100 \%)$ \\
\hline $\begin{array}{l}\text { Question } 11 \\
\text { Have difficulty in understanding English } \\
\text { conditional structures from grammar books }\end{array}$ & $\begin{array}{l}0 \\
(0 \%)\end{array}$ & $\begin{array}{l}13 \\
(13.27 \%)\end{array}$ & $18(18.37 \%)$ & $\begin{array}{l}52 \\
(53.06 \%)\end{array}$ & $\begin{array}{l}15 \\
(15.30 \%)\end{array}$ & $\begin{array}{l}98 \\
(100 \%)\end{array}$ \\
\hline
\end{tabular}

The data in Table 4 shows that the percentage of students choosing 'usually' for question 10 is so high, this is 40 $(40.82 \%)$ of all 98 informants, $4(4.08 \%)$ out of them chose 'always', they couldn't be successful in understanding English conditional structures. Only $3(3.06 \%)$ or $28(28.57 \%)$ claimed that English conditional structures were not difficult since it was clearly explained by the teacher right in the classroom.

How about English conditional structures presented in grammar books? Books have been considered as the best teacher or the best friends to the students. They don't have much time in the classroom while the knowledge of English conditional structures is so wide, both the time and the ways for self studying at home are necessary. The informants also spend much time on learning that point through grammar books. However, up to $52(53.06 \%)$ students reported that the explanations of English conditional structures were not easy to understand; and 15 (15.30\%) of them had to admit that they always had problems with getting to understand it from such materials. For this question, none of them ( $0 \%)$ claimed that they understood well what is written in grammar books about this grammar point.

For all the difficulties that the informants in the study discussed above, some questions were posed to find out the possible causes of these problems. Question 12 was designed to see that if the first language also affected the students' understanding of English conditional structures (see Table 5). 
TABLE 5.

POSSIBLE CAUSES OF THE STUDENTS' PROBLEMS

\begin{tabular}{|c|c|c|c|c|c|}
\hline Question 12 & Strongly agree & Agree & No opinion & Disagree & Total \\
\hline English conditional structures are difficult & 3 & & 12 & & \\
\hline $\begin{array}{l}\text { since they are different from those in your } \\
\text { first language }\end{array}$ & $(3.06 \%)$ & $\begin{array}{l}74 \\
(75.52 \%)\end{array}$ & $(12.24 \%)$ & $\begin{array}{l}9 \\
(9.18 \%)\end{array}$ & $98(100 \%)$ \\
\hline Question 13 & Strongly agree & Agree & No opinion & Disagree & Total \\
\hline $\begin{array}{l}\text { Time for presenting English conditional } \\
\text { structures in the classroom is too short }\end{array}$ & $\begin{array}{l}4 \\
(4.08 \%)\end{array}$ & $\begin{array}{l}78 \\
(79.59 \%)\end{array}$ & $\begin{array}{l}7 \\
(7.15 \%)\end{array}$ & $\begin{array}{l}9 \\
(9.18 \%)\end{array}$ & $98(100 \%)$ \\
\hline
\end{tabular}

While 12 out of 98 respondents had no opinion about this, $9(9.18 \%)$ of them disagreed, the rest of $77(78.58 \%)$ acknowledged that their native language (Vietnamese) really had a strong influence on their acquisition of English conditional structures, seven of whom expressed their opinion a little more strongly by choosing the option 'strongly agree'. All these percentages prove that the mother tongue plays a crucial role in the EFL learning and teaching.

Question 13 sought to investigate the learners' perception towards the influence of time for presenting English conditional structures in classroom. The percentage of students agreeing and strongly agreeing that the time was too short is higher than that of question 12 with 78 agreements and 4 strong agreements. Only $9(9.18 \%)$ of them disagreed. In fact, it is known that one grammar point can't be understood well if the time for presenting as well as practice is too short.

Students' mistakes on English conditional structures

TABLE 6.

STUDENTS' MISTAKES ON ENGLISH CONDITIONAL STRUCTURES

\begin{tabular}{|c|c|c|c|c|c|c|}
\hline & Never & Rarely & Sometimes & Usually & Always & Total \\
\hline $\begin{array}{l}\text { Question } 14 \\
\text { Using the wrong tenses }\end{array}$ & $\begin{array}{l}11 \\
(11.23 \%)\end{array}$ & $\begin{array}{l}6 \\
(6.12 \%)\end{array}$ & $\begin{array}{l}43 \\
(43.88 \%)\end{array}$ & $\begin{array}{l}28 \\
(28.57 \%)\end{array}$ & $\begin{array}{l}10 \\
(10.20 \%)\end{array}$ & $98(100 \%)$ \\
\hline $\begin{array}{l}\text { Question } 15 \\
\text { Using the wrong } \\
\text { conditional adverbs }\end{array}$ & $\begin{array}{l}44 \\
(44.90 \%)\end{array}$ & $\begin{array}{l}24 \\
(24.49 \%)\end{array}$ & $16(16.33 \%)$ & $\begin{array}{l}14 \\
(14.28 \%)\end{array}$ & $\begin{array}{l}0 \\
(0 \%)\end{array}$ & $\begin{array}{l}98 \\
(100 \%)\end{array}$ \\
\hline
\end{tabular}

Responding to Question 14, over half of the respondents (10.20\% always, $28.57 \%$ usually, $43.88 \%$ sometimes) reported that this is really a serious mistake. It happened to nearly all our students. Just a few of them, 11students $(11.23 \%)$ never made this mistake and 6 of them rarely got it. Through these percentages, it can't be denied that the English background knowledge of students is important. It helps them a lot in achieving the further knowledge.

The data in Table 6 also illustrates the adoption of wrong conditional adverbs. This is surprisingly high with 41 $(41.84 \%)$ and 17 (17.35\%) for 'sometimes' and 'usually', fewer of them never forgot it.

\section{B. Teachers' Responses to the Interview}

Firstly, all 15 teachers in the interview expressed their depressing feelings when they had to teach grammar to a lot of students whose English backgrounds were not very good and quite different from each other. All of them strongly claimed that they had tried to think of a various ways to teach this grammar point, but they were in vain. Only a few students were up to their expectation. They were afraid that if they concentrated much on low-performing students in order to help them get good knowledge of it, this would make the others whose English grammar were fairly good feel bored, which would lead to the depressing atmosphere in the classroom. Otherwise, if they taught so fast, just some good students could get the point while other worse students couldn't keep pace with, they were certainly left behind. So, it is really difficult for teachers to transfer this point successfully to all the students and the time would be not enough for other points in one semester with only 45 teaching periods (one period for 45 minutes).

Secondly, most of the informants reported to the interviewer that they were surprised to see that the EFL students in the university had a lot of problems in using conditional adverbs. These were taught carefully at high school, so they thought these mistakes couldn't be made again at university. The teachers were expecting some more other mistakes which were not very common and much more difficult than these.

Next, according to the teachers, there were a number of causes to these mistakes. The first and most important cause was the way of teaching and learning English grammar at high school, which made students find it hard to have a clear understanding of how to use English conditional structures in practice, especially in writing. The next cause might be the influence of the native language. The last but not least was our students' study behaviour. In fact, they didn't pay much attention to learn English grammar and they didn't spend enough time on practicing grammar points, which later caused them to forget or to be less confident of its formation or its usage.

Finally, in the interview, our teachers also suggested some implications for teaching this point at University for Natural Resources and Environment, Ho Chi Minh City (UNRE-HCMC). For them, the allotted time for this should be thought more for each class with different levels; the teachers should manage themselves and their teaching method so as to make students enjoy the class.

\section{CONCLUDING ThOUGHTS}


In order to be successful in teaching English conditional structures, teachers of English try their utmost:

- to know learners' needs, their English levels in order to find out the best way to teach them, and also to make them enjoy in grammar learning.

- to select the best and easy-to-understand materials for students to learn in class and at home.

- to diversify ways to present or practice grammatical items in class to motivate students to learn.

Speaking about the role of motivation in teaching and learning a foreign language, Gass and Selinker (1994, p. 250, 251) stated: "A social psychological factor frequently used to account for differential success in learning a second language is motivation. This has an intuitive appeal. It makes sense that individuals who are motivated will learn another language faster and to a greater degree.'

Effective teachers of English as a second or foreign language must have a mastering of the content they are teaching - the English language itself. This entails much more than being a native speaker of English. All teachers always improve themselves with all the knowledge of English grammar. They have to master every aspect of English grammar as much as they can. It can't be denied that the teachers with well-prepared lesson plans will have more chances to be successful than others with any preparation. The knowledge is so wide, but good teachers are ones who can find out ways to transmit all necessary points to students in short allotted time with their students' clear understanding as the final outcome.

Whether students could get one grammar point successfully or not, it completely depends much on themselves. All of them must be aware 5 periods spent for teaching and learning English conditional structures in class is indeed not enough for them to thoroughly master such a grammatical point. Apart from carefully learning at school, they have to manage time for self studying outside the classroom and at home with their own materials. When they find difficulties in understanding and using English conditional structures, they have to note them down and soon ask teacher to explain what they find it difficult to understand or use. Besides, it is a must to remember that they need practice a lot for any grammatical point, especially English conditional structures because this is complicated with various cases. Students should also be aware that in the teaching or learning process, there are stages such as presentations and explanations, and practices. In the presentation and explanation stages, teachers will try their best to present and explain every grammar point in a simple and clear way so that they may get the point. But it is advisable that in order to let them find it less difficult in understanding the point, they had better prepare themselves at home by reading this point provided in the school grammatical material.

The study was carried out with the assistance of only 15 teachers of the Department of Foreign Languages at University for Natural Resources and Environment, Ho Chi Minh City (UNRE-HCMC), and 98 EFL students. The research was designed only to find out students' mistakes in learning English conditional structures. The study was also expected to discover causes to these mistakes with the hope of improving students' understanding of this grammar point. Further studies, however, can be carried out with other data collection methods in addition to questionnaire or interview used in this research. Class observation to obtain data on how teachers transmit all knowledge of English conditional structures to students in class, or questionnaire to all the teachers to get more necessary information for the study.

\section{REFERENCES}

[1] Celce-Murcia, M. \& Larsen-Freeman, D. (1999). The Grammar Book: an ESL/EFL Teacher's Course. Boston: Heinle \& Heinle. [2] Covitt, R.I. (1976). Some Problematic Grammar Areas for ESL Teachers. Unpublished M.A. thesis in TESL, UCLA.

[3] Gass, S.M \& Selinker, L. (1994). Second Language Acquisition: An Introductory Course. New Jersey: Lawrence Erlbaum Associates, Inc.

[4] Nunan, D. (1992). Research methods in language learning. Cambridge: Cambridge University Press.

[5] Skehan, P. (1989). Individual differences in second language learning. London: Edward Arnold.

Luu Trong Tuan is currently an EFL teacher at Ho Chi Minh City University for Natural Resources and Environment. He received his M.TESOL from Victoria University, Australia in 2004. Besides his focus on TESOL, his recent publications such as Language Transfer is Cultural Transfer between Communities, Social Sciences Review, No. 11, 2004, pp. 60-63; and Principles for Scientific Translation, Social Sciences Review, No. 8, 2004, pp. 63-67; and Building Vietnamese Medical Terminology via Language Contact, Australian Journal of Linguistics, Vol. 29, No. 3, September 2009, pp. 315-336 show his interest in language contact and translation areas. 